\title{
BIOCHEMICAL CHANGES IN DEVELOPING SEEDS OF PIGEONPEA (CAJANUS CAJAN)*
}

\author{
U. Singh, R. Jambunathan and A. Narayanan $\dagger$ \\ International Crops Research Institute for the Semi-Arid Tropics (ICRISAT), ICRISAT Patancheru P. O., 502 324, Andhra \\ Pradesh, India
}

(Revised received 15 October 1979)

Key Word Index-Cajanus cajan; Leguminosae, pigeonpea; carbohydrates; proteins; amino acids; development.

\begin{abstract}
Soluble sugars, starch, soluble nitrogen and protein nitrogen were studied in developing seeds of 3 cultivars of pigeonpea. When expressed on a per seed basis soluble sugars increased up to 35 days after flowering and then declined slightly. Rapid starch accumulation was observed between 14 and 28 days after flowering. The levels of soluble nitrogen and protein nitrogen underwent rapid changes during the same period. Amino-acid composition of seed protein was also studied at different stages of maturation. Sodium dodecyl sulphate polyacrylamide gel electrophoresis of salt-soluble proteins revealed that seed storage globulins are formed after 14 days of flowering and do not change much during later stages of maturation.
\end{abstract}

\section{INTRODUCTION}

Carbohydrates and proteins are the main constituents of many legume seeds. During the maturation of legume seeds, these constituents are stored in the cells of cotyledons.

Pigeonpea is one of the important pulse crops in India and is grown in the tropical and subtropical regions of the world. Its seeds are an important source of protein in the human diet. Changes in the protein nitrogen and soluble nitrogen of developing and germinating seeds of pigeonpea have been reported recently [1]. So far as the authors are aware, information is not available on the changes in the carbohydrates, amino acids and proteins in developing seeds of pigeonpea. In this paper we report the results of such a study.

\section{RESULTS AND DISCUSSION}

Changes in dry and fr. wt observed for 3 cultivars (cvs) of pigeonpea are shown in Fig. 1. Between 14 and 28 days after flowering, a large increase in seed size was observed. Fr. wt per seed reached a maximum 28 days after flowering, whereas dry. wt per seed increased up to 35 days after flowering in all the cvs studied. After 35 days of flowering, a slight increase in dry seed wt was observed in the case of $\mathrm{Hy}-3 \mathrm{c}$ and ICP-1 and did not change much in the case of ST-1.

\footnotetext{
* Contribution from the International Crops Research Institute for the Semi-Arid Tropics (ICRISAT). Published with the approval of the Director as Journal Article No. 102.

$\dagger$ Present address: Professor of Crop Physiology, Andhra Pradesh Agricultural University, Rajendranagar, Hyderabad -500030 , A.P., India.
}

\section{Soluble sugars and starch content}

Changes in the level of soluble sugars during maturation are shown in Fig. 2. Soluble sugars, as per cent of the dry wt, continously increased up to 14 days after flowering, then showed a sharp decline and thereafter remained more or less unchanged. However, when the soluble sugars were expressed as $\mathrm{mg}$ per dehusked seed, an increasing trend was observed up to 35 days after flowering and then declined slightly.

Starch content in the developing grains was determined and changes in starch level as per cent of dry wt and $\mathrm{mg}$ per dehusked seed are plotted in Fig. 3. Dry wt of starch content at 14 days after flowering was $17.4 \%$ in ST-1, $20 \%$ in $\mathrm{Hy}-3 \mathrm{c}$, and $27 \%$ in ICP- 1 and this increased to $61.9,63.2$ and $62.4 \%$, respectively, 21 days after flowering. But the amount of starch per dehusked seed continued to increase up to 35 days after flowering in all cvs studied and then it showed slight changes towards maturation. It appeared that rapid starch accumulation occurred during the period between 14 and 28 days after flowering. This was also accompanied by changes in the levels of soluble sugars during the same period. Hence, there appeared to be an intense biochemical activity during the period between 14 and 28 days after flowering.

\section{Soluble nitrogen and protein nitrogen}

The percentage of soluble nitrogen and soluble nitrogen per seed in these cvs are plotted in Fig. 4. The soluble nitrogen as per cent of dry wt increased up to 14 days after flowering, then showed a sharp decline and became constant at later stages of maturation. On the other hand, soluble nitrogen expressed as $\mu \mathrm{g}$ per seed increased up to 28 days after flowering, and then became constant in the case of ICP-1 but showed a slight increase in the case of $\mathrm{Hy}-3 \mathrm{c}$ and ST-1. Soluble 


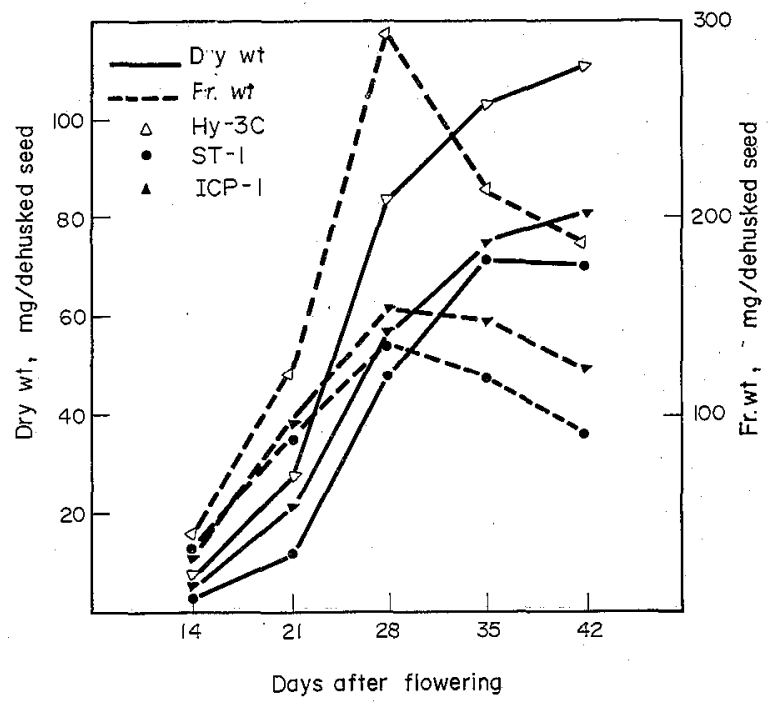

Fig. 1. Grain matter accumulation at different stages of maturation.

nitrogen calculated as proportion of the protein nitrogen (values not reported) increased up to 14 days after flowering and then progressively decreased as the grain developed. However, a sharp decline in the levels of soluble nitrogen during the: period between 14 and 28 days after flowering (Fig. 4) indicated that during this period the amino acids were utilized at a higher rate for protein synthesis. Furthermore, this observation was confirmed by electrophoresis as seed storage proteins could be detected after only 14 days of flowering.

Protein nitrogen values in these cvs were obtained by subtracting soluble nitrogen from total nitrogen. Protein nitrogen, expressed as per cent of dry wt, decreased gradually up to 21 days after flowering in all the $3 \mathrm{cvs}$, and then remained more or less unchanged except for the ST-1 which showed a slight increase 35 days after flowering (Fig. 5). The amount of protein,

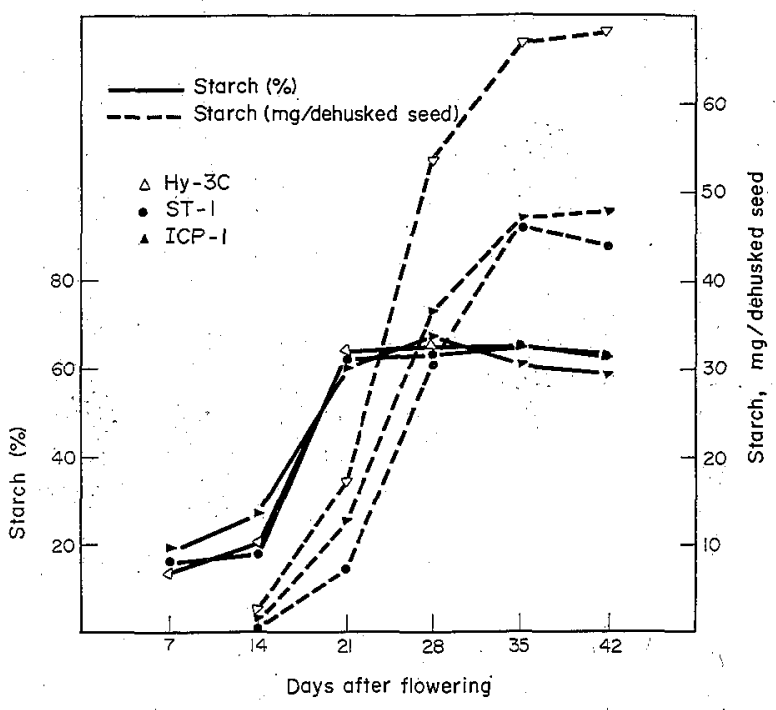

Fig. 3. Starch content at different stages of maturation.

expressed as $\mathrm{mg}$ per seed, increased up to 35 days after flowering and thereafter declined in the case of ST-1 and slightly increased in the case of $\mathrm{Hy}-3 \mathrm{c}$ and ICP-1.

\section{Electrophoretic patterns of salt-soluble proteins}

Extracts of salt-soluble proteins of $\mathrm{Hy}-3 \mathrm{c}$ and ST-1 were studied for their electrophoretic patterns. Protein bands were not detected in the samples taken 7 and 14 days after flowering, although Lowry's protein reaction was positive. This could be attributed to the presence of small peptides in the early stages of maturation. The protein bands of varying intensity appeared at 21 days after flowering. The salt-soluble proteins had several sub-units that appeared in the order of decreasing MW (Figs. 6 and 7). The seed globulins of mature pigeonpea seed, consisting of 9 sub-units, have been reported by others [2]. However, it would be difficult to explain the changes that occur

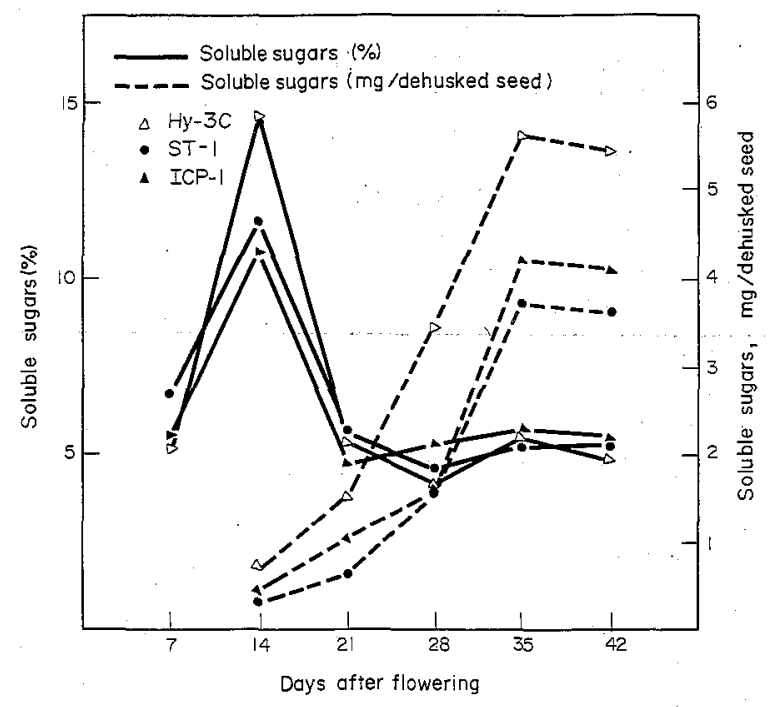

Fig. 2. Soluble sugars at different stages of maturation.

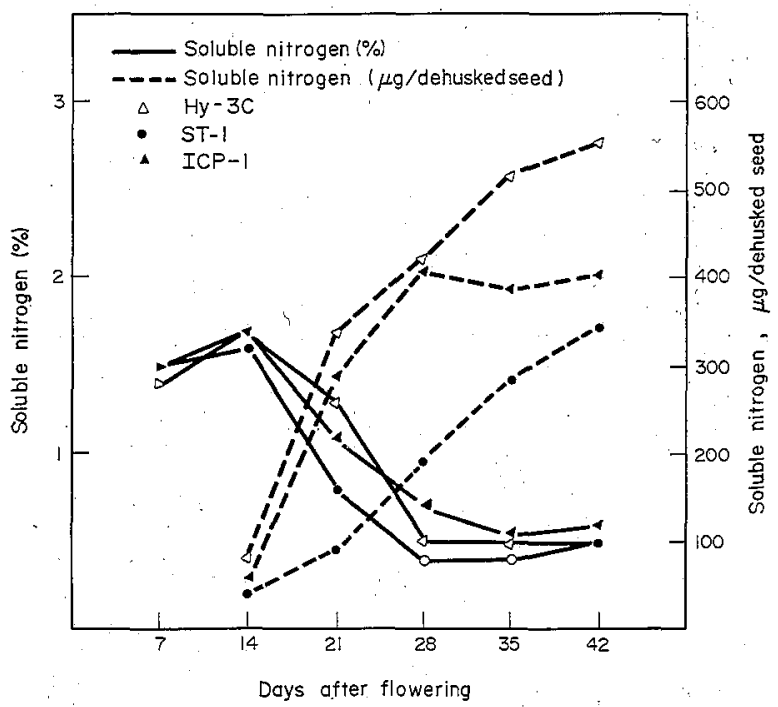

Fig. 4. Soluble nitrogen at different stages of maturation. 


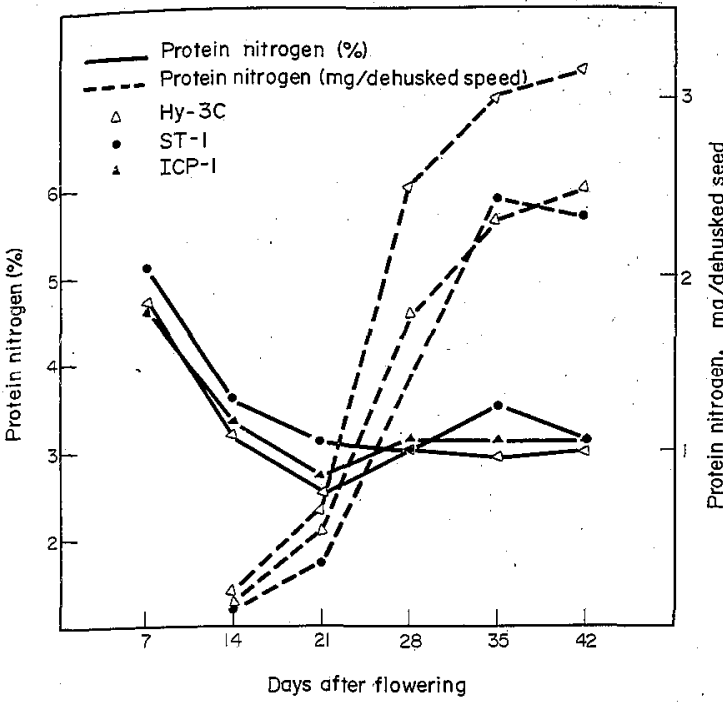

Fig. 5. Protein nitrogen at different stages of maturation.

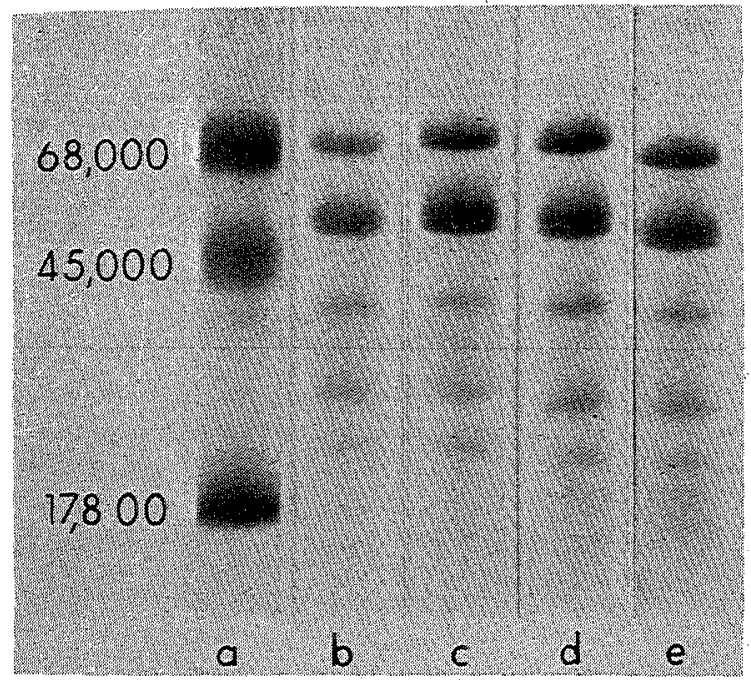

Fig. 6. Electrophoretic patterns of seed storage proteins during maturation of $\mathrm{Hy}-3 \mathrm{c}$. a: Std proteins; $b, c$; and e: samples from $21,28,35$ and 42 days after flowering, respectively.

with respect to different globulins which may have similar electrophoretic mobilities [3]. Several investigators have employed electrophoretic techniques to study the changes in the proteins at different stages of maturation $[4,5]$. As shown in Figs. 6 and 7, high MW protein components appeared to be the major seed proteins of pigeonpea in samples obtained 21 days after flowering. As we could not detect any bands in the samples taken 7 and 14 days after flowering, it appears that the protein synthesis starts between 14 and 21 days after flowering. Earlier workers [6] have also reported that protein synthesis in the case of Pisum sativum begins 8 days after flowering.

\section{Amino acid composition of proteins}

Protein amino acids of $\mathrm{Hy}-3 \mathrm{c}$ and ST- 1 at different stages of maturation were determined (Tables 1 and

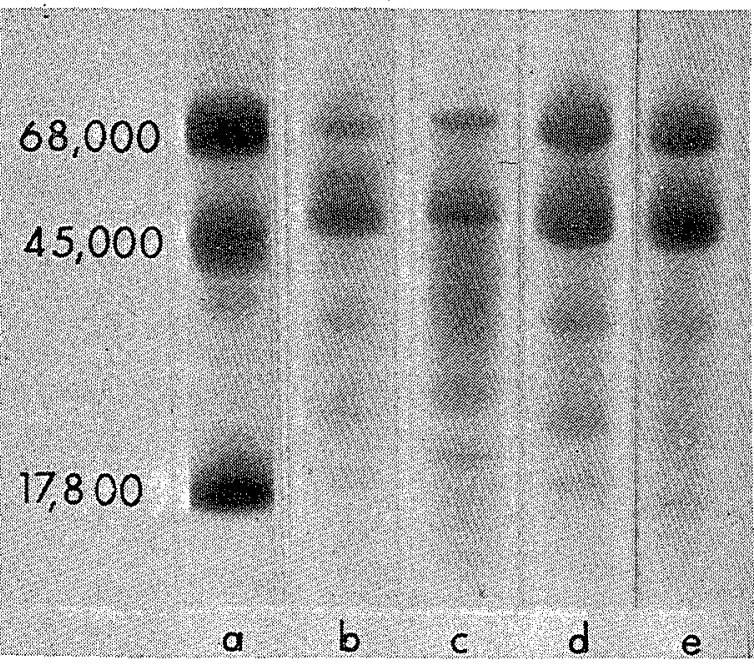

Fig. 7. Electrophoretic patterns of seed storage proteins during maturation of ST-1. a: Std proteins; b, c, d and e: samples

from $21,28,35$ and 42 days after flowering, respectively.

2). Tryptophan was not analysed. Cystine was not detected in the few samples obtained from the last stages of maturation, and the values are probably low for the samples of early stages of maturation. The reason for this is the partial destruction of this amino acid when $0.1 \mathrm{~N} \mathrm{NaOH}$ was used in our procedure for dissolving the residue after removal of soluble nitrogen. Earlier workers $[7,8]$ have reported that alkaline extraction of soybean meal resulted in the destruction of cystine and the formation of lysinoalanine.

Tables 1 and 2 show that the levels of many essential and non-essential amino acids changed significantly in both cvs, although no remarkable differences among them were revealed. The limiting essential amino acids, methionine and cystine, decreased during grain maturation. Leucine, isoleucine, valine and glycine decreased, whereas phenylalanine variably increased during grain maturation. Glutamic acid in $\mathrm{Hy}-3 \mathrm{c}$ gradually increased up to 35 days of flowering and up to 28 days in ST-1; it decreased at later stages of maturation. No definite trend was observed for other amino acids.

The limiting essential amino acids, methionine and cystine, are lower in the protein of mature cotyledons. The lower content of these amino acids might be due to (1) increase in storage proteins, which are relatively low in sulphur amino acids at later stages of development; (2) selective degradation of certain proteins during maturation and (3) lack of synthesis of some specific proteins because of lack of these amino acids in the free pool.

\section{EXPERIMENTAL}

Pigeonpea cvs, $\mathrm{Hy}-3 \mathrm{c}$, ST- 1 and ICP-1, grown at ICRISAT Centre near Hyderabad, India during 1976-1977 were tagged at flowering, and samples were collected periodically from 7 days after flowering to maturity. Seeds were removed from the pods, chilled in ice, and the seed coats were removed manually. Samples were then freeze-dried and ground to 100-mesh powder. Samples collected at 7 days 
Table 1. Amino acid composition of seed proteins of $\mathrm{Hy}-3 \mathrm{c}$ at different stages of maturation

\begin{tabular}{|c|c|c|c|c|c|c|}
\hline & \multicolumn{6}{|c|}{ Days after flowering } \\
\hline & \multicolumn{6}{|c|}{$\left(g / 16 \mathrm{~g} \mathrm{~N}^{*}\right)$} \\
\hline Lysine & 7.5 & 6.4 & 7.5 & 7.3 & 7.4 & 7.2 \\
\hline Histidine & 1.2 & 1.0 & 1.0 & 1.2 & 0.7 & 1.4 \\
\hline Arginine & 4.4 & 4.1 & 4.4 & 4.1 & 3.9 & 4.1 \\
\hline Aspartic acid & 12.3 & 11.8 & 12.1 & 12.3 & 11.8 & 11.2 \\
\hline Threonine & 4.3 & 4.2 & $3: 7$ & 3.4 & .2 .4 & $\because 3.4$ \\
\hline Serine & 4.9 & 3.7 & 4.9 & 5.0 & 3.8 & 5.3 \\
\hline Glutamic acid & 15.9 & 17.7 & 19.8 & 21.1 & 22.3 & 20.4 \\
\hline Proline & 5.4 & 6.3 & 5.0 & 5.1 & 5.2 & 5.4 \\
\hline Glycine & 5.9 & 5.4 & 4.9 & 4.4 & 4.0 & 4.3 \\
\hline Alanine & 7.0 & 8.0 & 5.9 & $5: 6$ & 6.8 & 5.2 \\
\hline Cystine & 0.3 & 0.3 & 0.2 & 0.2 & - & - \\
\hline Valine & 7.5 & 7.4 & 6.8 & 5.6 & 6.2 & 5.4 \\
\hline Methionine & 1.8 & 1.5 & 1.4 & 1.4 & 0.9 & 0.8 \\
\hline Isoleucine & 4.9 & 5.0 & 4.2 & 4.1 & 4.3 & 4.0 \\
\hline Leucine & 112 & 13.1 & 10.4 & 10.7 & 9.2 & 9.9 \\
\hline Tyrosine & 3.2 & 3.3 & 2.6 & 1.8 & 1.2 & 2.1 \\
\hline Phenylalanine & 5.6 & 6.2 & 7.1 & 7.9 & 6.9 & 8.0 \\
\hline Total & 103.3 & 105.4 & 101.9 & 101.2 & 97.0 & 98.1 \\
\hline Nitrogen recovery $(\%)$ & 91.4 & 93.8 & 92.6 & 86.2 & 88.5 & 85.6 \\
\hline
\end{tabular}

* Based on protein nitrogen.

Table 2. Amino acid composition of seed proteins of ST-1 at different stages of maturation

\begin{tabular}{|c|c|c|c|c|c|c|}
\hline \multirow[b]{3}{*}{ Lysine } & \multicolumn{6}{|c|}{ Days after flowering } \\
\hline & 7 & $14 \cdots$ & \multicolumn{2}{|c|}{${ }_{\left(\mathrm{g} / 16 \mathrm{~g} \mathrm{~N}^{*}\right)}^{28}$} & \multirow{2}{*}{$\begin{array}{r}35 \\
-7.5\end{array}$} & \multirow{2}{*}{$\begin{array}{l}42 \\
7.4\end{array}$} \\
\hline & 7.2 & 6.2 & 7.3 & 7.4 & & \\
\hline Histidine & 1.1 & $\because \quad 1: 4$ & 0.7 & 1.2 & 2.4 & 2.7 \\
\hline Arginine & 4.4 & 3.8 & 4.2 & 3.9 & 4.1 & 4.0 \\
\hline Aspartic acid & 12.7 & 12.2 & 12.9 & 11.9 & 11.1 & 11.3 \\
\hline Threonine & 4.4 & 4.3 & 3.8 & 3.3 & 3.4 & 3.2 \\
\hline Serine & 4.9 & 4.7: & 5.2 & 4.8 & 4.7 & 4.6 \\
\hline Glutamic acid & 15.5 & 16.4 & 19.9 & 21.7 & 19.7 & 19.3 \\
\hline Proline & 5.6 & 5.3 & 5.2 & 5.0 & 4.9 & 4.6 \\
\hline Glycine & 6.2 & 5.7 & 4.9 & 4.3 & 4.4 & 4.2 \\
\hline Alanine & 7.1 & 6.7 & 5.7 & 5.0 & 5.1 & $5: 1$ \\
\hline Cystine & 0.4 & 0.4 & 0.2 & - & 0.1 & 0.1 \\
\hline Valine & 7.7 & 7.5 & 6.6 & 5.4 & 5.2 & 5.1 \\
\hline Methionine & 1.8 & 1.6 & 1.2 & 1.0 & 1.2 & 0.9 \\
\hline Isoleucine & 5.1 & 5.0 & 4.4 & 3.9 & 3.7 . & 3.6 \\
\hline Leucine & 11.2 & 10.8 & 10.8 & 9.5 & 9.1 & 8.8 \\
\hline Tyrosine & .3 .8 & 4.0 & 2.4 & 2.7 & 2.7 & 3.1 \\
\hline Phenylalanine & 6.0 & 6.3 & 7.8 & 7.6 & 7.6 & 7.2 \\
\hline Total & 105.1 & 102.3 & 103.2 & 98.5 & 96.9 & 95.2 \\
\hline Nitrogen recovery (\%) & 96.8 & 94.2 & 94.5 & 90.3 & 87.6 & 84.7 \\
\hline
\end{tabular}

* Based on protein nitrogen.

were left intact due to their small size and the difficulties of removing the seed coats.

Total nitrogen and protein nitrogen. The standard microKjeldahl method [9] was used for the determination of soluble and total nitrogen in freeze-dried and defatted samples. For the extraction of soluble nitrogen different concns of TCA were studied, and at $10 \%$ TCA, nitrogen solubility was minimal. Further, using the biuret procedure it was observed that $10 \%$ TCA solubilizes a negligible amount of protein. Therefore, the soluble nitrogen was determined as follows. Freeze-dried and defatted samples $(150 \mathrm{mg})$ were homogenized with $15 \mathrm{ml} 10 \%$ (w/v) TCA and then shaken for $30 \mathrm{~min}$ in a mechanical shaker. The material was centrifuged $(12000 \mathrm{~g}$ for $15 \mathrm{~min})$ and the residue washed twice with $10 \%$ TCA. The supernatant and the washings were pooled and made up to $25 \mathrm{ml}$ : Aliquots were used for $\mathrm{N}$ 
estimation by the micro-Kjeldahl method. Protein $\mathrm{N}$ was calculated by subtracting the levels of soluble $\mathrm{N}$ from the total N.

Soluble sugars and starch content. Sugars were extracted from the freeze-dried and defatted sample, using $80 \% \mathrm{EtOH}$ in a Soxhlet apparatus. Extracts were evapd to dryness and the residue taken up in $\mathrm{H}_{2} \mathrm{O}$. Aliquots were used for estimation of soluble sugars by the $\mathrm{PbOH}-\mathrm{H}_{2} \mathrm{SO}_{4}$ method [10]. Starch content in the residue was determined by enzymatic hydrolysis [11], with minor modification as described below. Dried residue $(70 \mathrm{mg})$ was pläced in a conical flask and a few drops of $\mathrm{EtOH}$ and $10 \mathrm{ml}$ of $\mathrm{H}_{2} \mathrm{O}$ were added. Contents were dispersed and then autoclaved for $90 \mathrm{~min}$ at $1.34 \mathrm{~kg} / \mathrm{cm}^{2}$ $\left(125^{\circ}\right)$. The suspension was cooled to room temp. and $1 \mathrm{ml}$ $2 \mathrm{M}$ acetate buffer ( $\mathrm{pH} 4.8$ ) was added and the final vol. was made to $25 \mathrm{ml}$. An aliquot was incubated with $25 \mathrm{mg}$ of glucoamylase (Sigma) for $2 \mathrm{hr}$ at $55^{\circ}$. The glucose thus released was estimated, using the $\mathrm{PhOH}-\mathrm{H}_{2} \mathrm{SO}_{4}$ method.

Amino acid composition. The residue obtained after removing the soluble $\mathrm{N}$ was dissolved in $0.1 \mathrm{~N} \mathrm{NaOH}$ and the $\mathrm{N}$ content in the aliquot was determined by the microKjeldahl method. A suitable quantity of the aliquot (1.5$1.6 \mathrm{mg} \mathrm{N}$ ) was taken and neutralized by the addition of $0.1 \mathrm{~N} \mathrm{HCl}$. Conc $\mathrm{HCl}$ was then added to bring the final conc to $6 \mathrm{~N} \mathrm{HCl}$ and the contents were refluxed for $24 \mathrm{hr}$. After evaporating the $\mathrm{HCl}$ from the hydrolysate, the residue was dissolved in citrate buffer ( $\mathrm{pH} 2.2$ ). The amino acids were analysed in a Beckman $120 \mathrm{C}$ amino acid analyser. Mean coefficient of variability of analysis for different amino acids ranged between 1.3 and $9.0 \%$ except in the case of histidine and isoleucine where it was observed to be 11.9 and $11.3 \%$; respectively.

Extraction and electrophoresis of salt-soluble proteins. Seed proteins were extracted with $0.5 \mathrm{M} \mathrm{NaCl}$ in $0.01 \mathrm{MPi}$ buffer (pH 7) by shaking in a centrifuge tube for $1 \mathrm{hr}$ using a flour to solvent ratio of $1: 20(\mathrm{w} / \mathrm{v})$. Extracts were clarified by centrifugation at $10000 \mathrm{~g}$ for $15 \mathrm{~min}$ and used for electrophoresis. Protein content was estimated by the procedure of ref. [12]. SDS-acrylamide gel electrophoresis was performed according to the procedure of ref. [13] with minor procedural modifications in that the proteins were treated with $0.1 \%$ SDS and $0.1 \%$ 2-mercaptoethanol in $0.01 \mathrm{MPi}$ buffer ( $\mathrm{pH} 7.1$ ) for
$2 \mathrm{~min}$ at $100^{\circ}$. An aliquot containing $200 \mu \mathrm{g}$ protein was applied on each of the gel. Electrophoresis was carried out using $7.5 \%$ acrylamide gels in $\mathrm{Pi}$ buffer ( $\mathrm{pH} 7.1$ ) for $3.5 \mathrm{hr}$ at $5 \mathrm{~mA} /$ tube. Marker proteins used were human serum albu$\min (68000)$, ovalbumin (45000) and myoglobin (17800). Gels were stained in $0.25 \%$ Coomassie Brilliant Blue-R 250 in $\mathrm{MeOH}-\mathrm{H}_{2} \mathrm{O}-\mathrm{HOAc}(5: 4: 1)$. Destaining was accomplished in the same solvent with a ratio of $5: 88: 7$.

Acknowledgements-The authors wish to thank Mrs. Santosh Gurtu and Mr. A. L. Reddy for technical assistance during the investigation.

\section{REFERENCES}

1. Madhava Rao, K. V. and Rajeswara Rao, G. (1978) Indian J.Plant Physiol. 21, 197.

2. Gopalakrishna, T., Mitra, R. K. and Bhatia, C. R. (1977) Qual. Plant-Plant Foods Hum. Nutr. 27, 313.

3. Catsimpoolas; N. and Ekenstam, C. (1969). Arch. Biochem. Biophys. 129, 490.

4. Hall, T. C., Mcleester, R. C. and Bliss, F. A. (1972) Phytochemistry 11, 647.

5. Kondo, K., Mori, S. and Kójima, M. (1954) Bull. Res. Inst. Food Sci. Kyoto Univ. 15, 37.

6. Millerd, A. and Spencer, D. (1974) Aust. J. Plant Physiol. 1, 331.

7. DeGroot, A. P., Slump, P., Van Beek, L. and Feron, V. J. (1975) Severe alkali treatment of protein. 35th Ann. IFT Meeting, Chicago, U. S. A.

8. Liener, I. E. (1977) J. Am.' Oil Chem. 54, 454.

9. (1970) Association of Official Analytical Chemists; Official Methods of Analysis, 11th edn. Washington, DC.

10. Dubois, M. Gilles, K. A., Hamilton, J. K., Rebers, P. A. and Smith, F. (1956) Analyt. Chem. 28, 350.

11. Thivend, P., Christiane, M. and Guilod, A. (1972) in Methods in Carbohydrate Chemistry (Whistler, R. L. and BeMiller, J. N.; eds.) Vol. VI, p. 105. Academic Press, New York.

12. Lowry, O. H., Rosebroúgh, N. J., Farr, A. L. and Randall, R. L. (1951) J. Biol. Chem. 193, 265.

13. Weber, K. and Osborn, M. (1969) J. Biol. Chem. 244, 4406 . 